\title{
Causality of Fraud Detection
}

\author{
Darwis Lannai $^{{ }^{*}}$ and, Muslim Muslim ${ }^{2}$ \\ ${ }^{1,2}$ Department of Accounting, Faculty of Economic and Business, Makassar City, Indonesia \\ Email address: \\ *darwis.lannai@umi.ac.id,muslim.ak@umi.ac.id
}

\begin{abstract}
The purpose of this study is to examine the effect of experience, independence, implementation ethic and workload to fraud detection. Collecting data in this study using a questionnaire instrument with a sample of 52 auditors KAP in Makassar city using the saturated sampling technique. The analytical method used is the Partial Least Square (PLS) approach. The results of this study indicate that experience and implementation ethic had a positive and significant effect on fraud detection. While independence and workload had a positive but not significant influence on fraud detection.
\end{abstract}

Keywords: Experience, Independence, Ethics, Workload, Fraud Detection.

\begin{abstract}
Abstrak: Tujuan dari penelitian ini adalah untuk menguji pengaruh pengalaman, independensi, etika implementasi dan beban kerja terhadap deteksi kecurangan. Pengumpulan data dalam penelitian ini menggunakan instrumen kuesioner dengan sampel sebanyak 52 auditor KAP di kota Makassar dengan menggunakan teknik sampling jenuh. Metode analisis yang digunakan adalah dengan pendekatan Partial Least Square (PLS). Hasil penelitian ini menunjukkan bahwa pengalaman dan etika implementasi berpengaruh positif dan signifikan terhadap deteksi kecurangan. Sedangkan independensi dan beban kerja berpengaruh positif namun tidak signifikan terhadap deteksi kecurangan. Semakin tinggi pengalaman auditor, maka semakin mampu dan mahir auditor mengusai tugasnya sendiri maupun aktivitas yang diauditnya. Pengalaman juga membentuk auditor mampu menghadapi dan menyelesaikan hambatan maupun persoalan dalam pelaksanaan tugasnya, serta mampu mengendalikan kecenderungan emosional terhadap pihak yang diperiksa. Selain pengetahuan dan keahlian, pengalaman auditor memberi kontribusi yang relevan dalam meningkatkan kompetensi auditor.
\end{abstract}

Kata Kunci: Pengalaman, Independensi, Etika, Beban Kerja, Deteksi Penipuan.

\section{INTRODUCTION}

Currently, cases of fraud involving accountants are still being heard, which has an impact on the accounting profession's development. The accountant profession, which is entrusted with bringing benefits to society, primarily through the entities that hire them, is in direct opposition to widespread fraud. The involvement of auditors in numerous cases of fraud raises questions about the accounting profession and brings it to the attention of policymakers and the general public (Rahim et al., 2019). 
External auditors assigned to audits of these companies carry out the audit appropriately, including detection fracking, then nothing will happen these adverse cases. Business people have an excellent opportunity to dredge maximized profit, although in no way justified by law, let alone by ethical values. Several fraud cases involving names of public accountants, namely KAP Amir Abadi Jusuf, Aryanto, Mawar \& Rekan, related to the 2017 Annual Financial Report (LKT) of PT Tiga Pilar Sejahtera Food Tbk (AISA), which is still in the process of being investigated. The new management found that in the sales post, Rp. Six hundred sixty-two billion was misstated, there were accounts receivable up to Rp. 4Trillion, inventory, and fixed assets. Another case with KAP Tanubrata, Sutanto, Fahmi, Bambang \& Rekan sanctions suspension from the financial professional development center (P2PK) for 12 months. This sanction was due to a misstatement in the 2018 LKT of PT Garuda Indonesia Tbk.

The auditor's ability to detect fraud is a quality of himself by identifying and proving fraud to explain its improper financial statements. (Karyono, 2013) states that fraud is an act of deliberate execution that can lead to a material misstatement in the financial statements, which is the central aspect of an audit. Fraud detection is an action that aims to find fraud, who is the perpetrator, who is the victim, and why. The wear detection key is to be able to see any errors and irregularities.

The ability to detect fraud means that the process of detecting or determining a violation can lead to misstatements in the financial statements. Fraud can not only be found through the public accountant's audit process but also through a fraud detection cycle that involves management, internal auditors, external auditors, and forensic auditors. Fraud includes the following types: 1) Financial statements that contain fraud, namely errors or misstatements in a series of disclosures to deceive users; 2) Misuse of assets (misuse of assets), which involves cooperation due to other parties and fraudulent behavior of asset theft; 3) Corruption, namely other forms of fraud such as bribery and corruption, this type occurs most frequently in developing countries. These countries have weak law enforcement and still lack understanding of suitable management procedures, so that their integrity is still affected. Questioning, including abuse of power/conflicts of interest, bribery, illegal economy; 4) Computer-related fraud is a time crime, divided into computer tampering, theft of information and property, financial fraud or cash theft, and the illegal sale of computer services (Karyono, 2013).

Because fraud is uncommon, not every auditor has ever discovered a fraud case while auditing to support the auditor's ability to detect fraud that may occur during the audit. When it comes to detecting fraud, the auditor must be able to identify and identify possible causes of fraud quickly and evaluate indicators, such as fraud characteristics, audit standards, internal control systems, and document and individual testing.

The auditor's task in examining transactions and their cycles necessitates precision and expertise, particularly if accounting irregularities lead to fraud; the auditor must detect and provide solutions. In comparison to inexperienced auditors, people with extensive experience can find errors or abnormalities in financial statements and provide a more accurate explanation of their findings.

The auditor's experience influences fraud detection. An experienced auditor will find it easier to detect indications of fraud (Yulia and Nayang, 2018). (Dasila and Hajering, 2019) stated that auditors with more experience would have accuracy, accuracy, and responsiveness to errors or errors so that the auditor can properly find fraud.. 
The result of the research conducted by (Yanti and Herlin, 2019; Anto, Mustafa, \& Florensia, 2020) found that experience affects auditors' ability to detect fraud. Auditors can be said to be experienced in terms of the length of time and the number of examinations they have performed. Two important things experienced auditors have are formal education and audit experience. While, (Afiani et al., 2019; Rahim et al., 2019) found that auditors' experience did not affect their ability to detect fraud (Mulyadi, 2016).

\section{THEORITICAL REVIEW}

The attribution theory is used in this research. According to attribution theory, the behavior is linked to individual attitudes and characteristics; thus, knowing a person's attitude or characteristics and predicting their behavior in specific situations is only possible by observing their behavior. The causes of an event or the results obtained based on personal perception are attribution theory. The impact of fraud audit training on influencing auditors in carrying out their duties to detect possible fraud is explained using attribution theory in this study. It is hoped that by attending fraud audit training, auditors will detect the possibility of fraud. In this study, it was discovered that inexperienced auditors would make better decisions in the future. They will fully comprehend how to balance interests and skepticism to provide the correct opinion and detect fraud as soon as possible. Auditors with a lot of experience can get a good understanding of a lot of different audit issues. It also makes it easier for auditors to keep track of increasingly complex developments, making fraud detection easier. So here's the hypothesis for this study:

\section{H1 : Experience positif significantly influence fraud detection.}

Independence has an impact on the causality of fraud detection. Others find it difficult to influence independence as a mindset. Auditors must maintain independence in terms of honesty and fairness, a high sense of responsibility, giving opinions, not having special interests with customers, and so on. According to auditing standards, you must be a public accountant and use financial reports regularly. The more trustworthy an auditor is, and the more independent the auditor is, the easier it is for them to detect fraud.

Independence means that it is not easily influenced because the responsibility for carrying out its work is for the public interest (Sulistiyanti, 2020). If the expert auditor does not have an independent attitude, gathering evidence or information to detect fraud will be of no use because the information or evidence used to detect fraud has not been fully disclosed. After all, the auditor is not independent or does not represent the client. (Anto et al., 2020). Research from (Muslim et al., 2020) statement is independence requires auditors to form a public opinion as a professional profession and provide justice for all stakeholders.

The research conducted by (Indrawati et al., 2019; Sania et al., 2019) found that independence affects the ability of auditors to detect fraud. Auditor independence is closely related to the auditor's responsibility to detect fraud because of the element of independence, namely the honest attitude of the auditor in finding facts when auditing (Dasila and Hajering, 2019). Research from (Primasari et al., 2019; Peuranda et al., 2019) found that independence does not significantly affect auditors' ability to fraud detection.

The cognitive dissonance theory is used in this study. Cognitive dissonance is an unpleasant mental state that occurs when two human cognitions, behaviors, or attitudes 
conflict. According to cognitive dissonance theory, having an independent attitude is crucial when performing tasks. If auditors encounter a lot of cognitive disrespect in their auditing work, they must stand against it. They'll try to make up for the gap by changing their behavior and becoming more self-sufficient. In terms of independent attitude, it is critical to persuade and report users with this attitude. So here's the hypothesis for this study:

\section{$\mathbf{H 2}$ : Independence positif significantly influence fraud detection.}

Implementing auditor ethics can also have an impact on fraud detection. Auditor ethics is a moral guiding principle that auditors should follow when conducting audits to produce high-quality audits. Ethics are the rules and norms that govern human behavior, whether they are needed or not, and social institutions and professions follow them. If an accountant has moral values, they will always maintain ethics and follow the applicable accounting code of ethics (Amin, 2019). According to (Hassan 2019), auditors must follow applicable ethics to meet predetermined work quality standards and maintain public confidence in the accounting profession's services.

According to research by (Harahap and Putri, 2018) and (Idawati, 2020), implementing a code of ethics has an impact on fraud detection. Auditors will be able to detect fraud using the basic principles of professional ethics outlined in the auditor's code of ethics. The attribution theory is used in this research. The attribution theory is used in this research. By understanding the reasons for one's experience of these events, attribution theory explains how to understand a person's reactions to events around him. According to attribution theory, behavior is linked to individual attitudes and characteristics; thus, only by observing a person's behavior can one determine their attitude or characteristics, as well as predict their behavior in specific situations. When it comes to how auditors detect fraud, it will be seen what factors influence ethics. An ethical auditor performs his job with honesty and objectivity in order to detect fraud in his client's financial statements. The following is the hypothesis that has been proposed:

\section{H3 : Implementation ethic positif significantly influence fraud detection.}

Workload has an impact on fraud. The workload of auditors represents the amount of work that must be completed within a specific time frame. Workload as a factor in enhancing organizational performance and the quality of audit services produced. As a result, in order to achieve quality performance, the workload must be balanced and effective. The workload will occur when the auditor's work is not proportional to his time and abilities (Ulfa, 2015).

According to studies by (Sari and Helmayunita, 2018) and (Molina and Wulandari, 2018), auditor workload has a significant positive impact on their ability to detect fraud. The attribution theory is used in this research. By understanding the reasons for one's experience of these events, attribution theory explains how to understand a person's reactions to events around him. According to attribution theory, the behavior is linked to individual attitudes and characteristics; thus, knowing a person's attitude or characteristics and predicting their behavior in specific situations is only possible by observing their behavior. The workload of auditors will be determined by how they detect fraud. Due to some of the auditor's workload's adequacy and accuracy during the audit, it will be easier to 
detect fraud discovered during the audit. The following is the hypothesis that has been proposed:

\section{H4 : Workload negative significantly influence fraud detection.}

Researchers make decisions based on references from previous research (Idawati, 2020). Professional ethics and experience are put to the test against fraud detection in this equation. The difference is that this study includes two additional variables: independence and workload. Another distinction is the sample used in this study, which is the auditor KAP Makassar City, as opposed to the research (Idawati, 2020), which uses KAP samples in Central and South Jakarta.

An explanation of the framework is outlined in the hypothesis below.

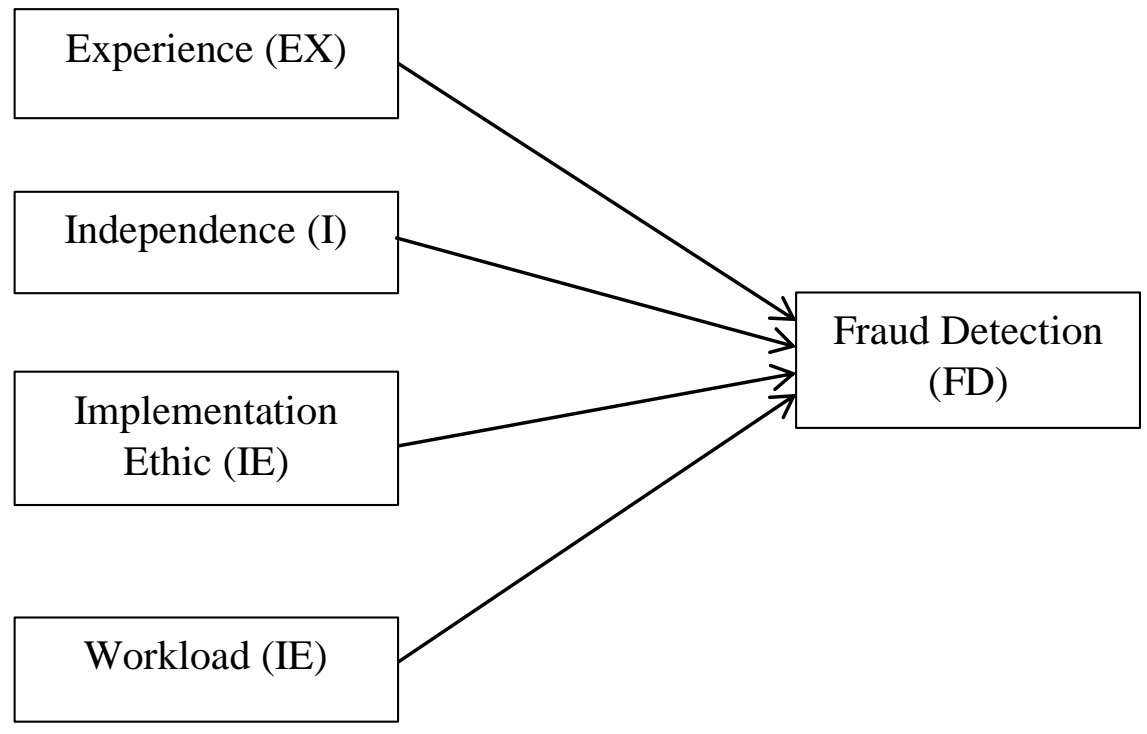

Figure 1. Research Model

The figure 1, explains that the independent variable is assumed to have a positive effect on the dependent variable.

\section{METHODS}

This study uses an explanatory research approach combined with a survey approach to see the problems and research objectives. The term "population" refers to all groups of people, events, or things that researchers are interested in studying (Sekaran \& Bougie, 2018). The information used in this study is primary data. The sample consisted of 52 people using the saturated sampling technique, and the observation, which is the population in this study, is all auditor KAP in Makassar City.

The objects of this research are experience, independence, implementation ethic, workload, and fraud detection. The data source is primary data through a questionnaire that has been distributed to auditors KAP in Makassar City. In this research five variables were 
measured by using a Likert Scale, from 1 to 5 where: $1=$ Strongly Disagree, $2=$ Disagree, $3=$ Neutral, $4=$ Agree and $5=$ Strongly Agree.

Data analysis using the Smart PLS structural equation model. Optimize the relationship between the dependent variable and the independent variable. PLS consists of external relationships (outer model or measurement model) and internal relationships (inner or structural models). (1) the measurement model (outer model) specifies the relationship between the indicator block and its latent variables, and (2) a structural model (inner model) specifies the relationship between latent variables.

\section{RESULTS}

This research succeeded in distributed 52 questionnaires to respondents. The data used in this study include gender, last position, years of service, and last education. Respondent description data is dominated by a female as many as 32 auditors $(61,5 \%)$ while the men are many 20 auditors $(38,5 \%)$. Having seen from the working period, it can be seen that the auditor's position is dominated by 34 auditors $(65,38 \%)$ by senior auditors and as many 18 auditors $(34,62 \%)$ as junior auditors. Having seen from the working period is dominated by 6-8 years work period as many 35 auditors $(67,30 \%)$, work period 3-5 years as many as 11 auditors $(21,15 \%)$ and work period $>8$ years as many as 6 auditors $(11,55 \%)$. While, judging from the education, it is known that the majority of S1 degree are 39 auditors (75\%) followed by $\mathrm{S} 2$ degree of master degree as many as 13 auditors (25\%).

Descriptive statistics describe data as information that is clearer and easier to understand. Descriptive statistics provide an overview or description of data seen from the average value, standard deviation, maximum and minimum.

Table 1. Descriptive Statistics

\begin{tabular}{lccccc}
\hline & N & Minimum & Maximum & Mean & Std. Deviation \\
\hline Experience (X1) & 52 & 3.00 & 5.00 & 3.9935 & .42249 \\
Independence (X2) & 52 & 3.00 & 5.00 & 4.0131 & .53272 \\
Implementation Ethic (X3) & 52 & 3.00 & 5.00 & 4.1092 & .47944 \\
Workload (X4) & 52 & 3.00 & 5.00 & 3.8962 & .44720 \\
Fraud detection (Y) & 52 & 3.00 & 5.00 & 4.1608 & .49125 \\
\hline
\end{tabular}

Source : Data processed (2020) 
Table 2. Result Outer Loading

\begin{tabular}{lcc}
\hline \multicolumn{1}{c}{ Construct } & Indicator & Outer Loading \\
\hline Experience (X1) & X1.1 & 0.706 \\
X1.2 & 0.831 \\
X1.3 & 0.839 \\
X1.4 & 0.800 \\
Independence (X2) & X1.5 & 0.807 \\
& X2.1 & 0.835 \\
X2.2 & 0.860 \\
Implementation Ethic (X3) & X2.3 & 0.788 \\
& X2.4 & 0.835 \\
X2.6 & 0.808 \\
X3.1 & 0.840 \\
X3.2 & 0.902 \\
Xraud detection (Y) & X3.3 & 0.765 \\
Xorkload (X4) & X3.5.6 & 0.806 \\
& X3.7 & 0.790 \\
X3.8 & 0.802 \\
X4.1 & 0.774 \\
X4.2 & 0.773 \\
& X4.3 & 0.637 \\
X4.4 & 0.756 \\
X4.5 & 0.856 \\
Y1.1 & 0.860 \\
Y1.2 & 0.868 \\
Y1.3 & 0.863 \\
Y1.4 & 0.791 \\
Y1.5 & 0.844 \\
Y1.6 & 0.788 \\
Y1.7 & 0.886 \\
Y1.8 & 0.851 \\
& & 0.774 \\
& & 0.834 \\
& & 0.582 \\
& & 0.711 \\
\hline
\end{tabular}

Source : Data processed (PLS, 2020).

Table 1 shows the descriptive statistics of each variable in this study. The analysis results using descriptive statistics on the experience variable (X1) show a minimum value of 3.00, a maximum value of 5.00, a mean (average) of 3.993 with a standard deviation of 0.422 . Furthermore, the independence variable analysis (X2) shows a minimum value of 3.00, a maximum value of 5.00, a mean (mean) of 4.013, and a standard deviation of 0.532 .

The implementation ethic variable (X3) shows a minimum value of 3.00, a maximum value of 5.00, a mean (average) of 4.109 with a standard deviation of 0.479 . The workload variable (X4) shows a minimum value of 3.00, a maximum value of 5.00, a mean (average) of 3.896, and a standard deviation of 0.447 . The fraud detection variable (Y) shows a minimum value of 3.00 , a maximum value of 5.00 , a mean (average) of 4.160 with a 
standard deviation of 0.491 . This means that the data distribution of experience, independence, implementation ethic, workload, and fraud detection to collect and identity that the data collected is relatively good.

The measurement model or outer model with a reflective index is evaluated by the convergence and discriminative validity of the index and the index block's composite reliability (Sugiyono, 2015).

Each indicator in the research variable has the most significant cross loading value on the variable it forms than the cross loading value on other variables. Based on the results obtained, it can be stated that the indicators used in this study have good discriminant validity in compiling their respective variables. Show that the construct correlation of experience, independence, implementation ethic, and workload with each indicator is higher than 0,5 at the meaning constructs fully fulfill the validity criteria.

Table 3. Average Variance Extracted

\begin{tabular}{ll}
\hline$\quad$ Construct & AVE \\
\hline Experience (X1) & 0.647 \\
Independence (X2) & 0.707 \\
Implementation Ethic (X3) & 0.695 \\
Workload (X4) & 0.719 \\
Fraud detection (Y) & 0.623 \\
\hline
\end{tabular}

Source : Data processed (PLS, 2020).

In this study, the Average Variance Extracted (AVE) value of all variables was $>0.50$, so it can be concluded that all constructs have become an appropriate measurement tool.

Table 4. Composite Reliability and Cronbach alpha

\begin{tabular}{lcc}
\hline \multicolumn{1}{c}{ Construct } & Composite Reliability & Cronbachs Alfa \\
\hline Experience (X1) & 0.916 & 0.893 \\
Independence (X2) & 0.935 & 0.922 \\
Implementation Ethic (X3) & 0.922 & 0.904 \\
Workload (X4) & 0.927 & 0.902 \\
Fraud detection (Y) & 0.929 & 0.911 \\
\hline
\end{tabular}

The composite reliability and Cronbach alpha results show that each variable has a value greater than 0.70 , indicating that all instrument variables are reliable. The inner model is a test that involves evaluating the study's hypothesized latent constructs.

Table 5. R Square Test

\begin{tabular}{ll}
\hline Construct & R Square \\
\hline Fraud Detection & 0,576 \\
\hline
\end{tabular}

$\mathrm{R}$ square value is a goodness fit model test. Changes in the value of $\mathrm{R} 2$ are used to explain the effect of certain exogenous latent variables on endogenous latent variables, whether they have a substantive effect. The $\mathrm{R}$ square value for the fraud detection variable is 0.576 or $57.60 \%$. The fraud detection variable can be explained by the variables 
experience, independence, implementation ethic, and workload is $57.60 \%$. In comparison, the remaining $42.40 \%$ can be explained by variables that were not found in this study. The result of processing using the PLS can be shown in figure 2 .

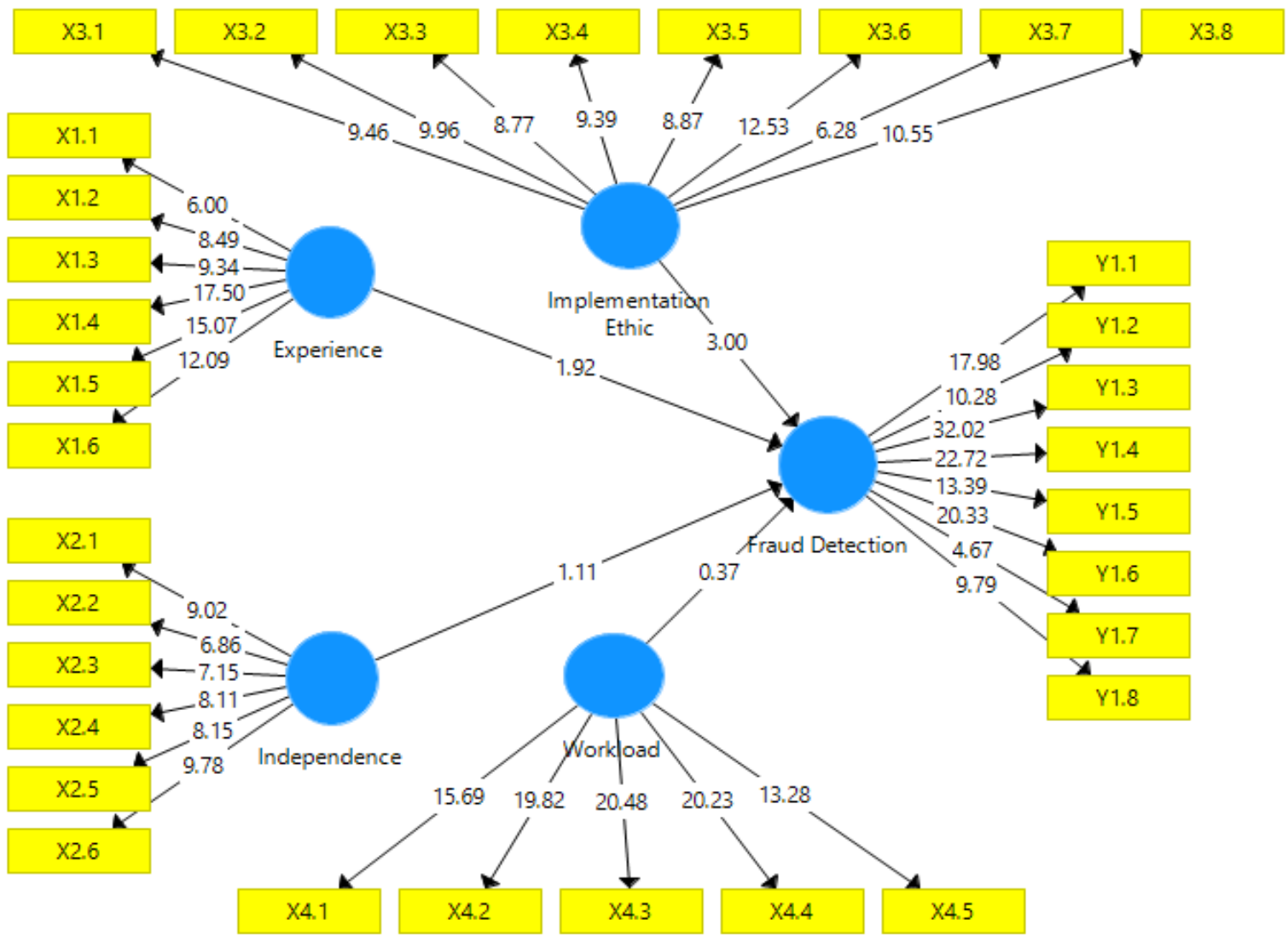

Figure 2. Result of PLS

Source : Data Processed (PLS, 2020)

The result of PLS processing in Figure 2 is summarized in Table 6 below as the hypothesis test result. The results can be used to respond to the hypothesis in this study, based on the data processing. The T-Statistics and the P-Values were assessed for the hypothesis testing in this study..

Table 6. The Result of Hypotesis Test

\begin{tabular}{ccccc}
\hline Iner Variable & $\begin{array}{c}\text { Original } \\
\text { Sample }\end{array}$ & $\begin{array}{c}\text { T } \\
\text { Statistics }\end{array}$ & P Values & Result \\
\hline $\begin{array}{c}\text { Experience with } \\
\text { Fraud detection }\end{array}$ & 0.352 & 1.953 & 0.050 & Hypothesis 1 accepted \\
\hline $\begin{array}{c}\text { Independence with } \\
\text { Fraud detection }\end{array}$ & 0.164 & 1.030 & 0.303 & Hypothesis 2 is rejected \\
\hline $\begin{array}{c}\text { Implementation ethic with } \\
\text { Fraud detection }\end{array}$ & 0.345 & 3.109 & 0.003 & Hypothesis 3 accepted \\
\hline $\begin{array}{c}\text { Workload with } \\
\text { Fraud detection }\end{array}$ & 0.086 & 0.392 & 0.695 & Hypothesis 4 is rejected \\
\hline
\end{tabular}


The research output shows that hypothesis 1 is accepted; experience has a significant positive effect on fraud detection with the coefficient value of the experience variable of 0.352 , a significant level of 0.050 , or a significance level of 0.05 . This means that the more work experience the auditor has, the easier it will be to detect fraud symptoms.

The following output shows that hypothesis 2 is rejected. Independence does not significantly affect fraud detection with the coefficient value of the independence variable of 0.164 , a significant level of 0.303 or not at the 0.05 significance level. This means that the independence of auditors has not been able to improve their ability to fraud detection.

The output of this study also finds that hypothesis 3 is accepted. Implementation ethics has a significant positive effect on fraud detection with a coefficient value of 0.0345 , a significant value of 0.003 , or at the 0.05 significance level. This means that auditors who implement ethics will be able to fraud detection.

The output of this study shows that hypothesis 4 is rejected. The workload does not significantly affect fraud detection with a coefficient value of 0.086 , has a significant level of 0.695 , or is at a significance level of 0.05 . This indicates that the workload that is felt to be incompatible with its capacity will not affect fraud detection.

\section{DISCUSSION}

Experience with fraud detection. This study found that experience has a positive and significant effect on fraud detection so that the first hypothesis (H1) is accepted. These results explain that the experience possessed by auditors can improve their competence and technical skills in carrying out audits. The examination referred to is an examination that refers to a general standard so that an auditor with good experience can accurately determine the sample area of the examination so that the effectiveness and efficiency of fraud detection can be achieved. Another indicator, namely the length of time the auditor has worked, will determine auditor selection, understanding, and reaction to the scope of work. The structure of the assertion assessment process is maximized. The results of our study also show that the more often the auditor performs his duties, the more auditing skills he has in carrying out examinations and his ability to detect. An auditor who performs inspection work continuously will impact the speed and reliability of completing his duties. The auditors understand the technical work and have experienced many obstacles or errors in their work to be more careful and careful in completing it. It implies that the more extensive the experience gained by an auditor, the better the auditor will understand the technical implementation of auditing related to problems on the object of examination. On the other hand, auditors with little experience are less familiar with the problems under examination, making it difficult to detect fraud.It makes fraud detection ineffective and accurate. This study supports attribution theory, where the behavior of auditors in fraud detection is closely related to the experience they have. The more experience an auditor has, the more capable and proficient the auditor is in mastering his duties and activities audited. Associating research results with attribution theory has implications that experienced audiences will make better decisions in the future. They will fully understand how to balance interest and skepticism to provide the correct opinion and detect fraud as quickly as possible. Auditors with much experience can gain a good understanding of many different audit issues. It also makes it easier for auditors to track increasingly complex developments, making fraud detection easier. 
Experience also makes auditors have the ability to face and resolve challenges and problems in carrying out their duties and control emotional tendencies towards the party being examined. In addition to knowledge and expertise, the experience of auditors is a relevant contribution to improving the competence of auditors so that auditors have more moral behavior for fraud detection. This research supports the research conducted (Molina and Wulandari, 2018; Yanti and Herlin, 2019), which describes that experience influences fraud detection. (Anto et al., 2020) also, describe that experience will guide auditors to find types of fraud and find solutions when facing fraud cases. It is assumed that experienced auditors can better detect fraud than inexperienced auditors. Because, both technically and psychologically, a person's expertise will depend on experience. (Sari et al., 2018).

Independence from fraud detection. This study found that independence did not affect fraud detection, so that the second hypothesis $(\mathrm{H} 2)$ was rejected. It is explained that auditors as respondents already have long work experience and are highly educated, so it is believed that auditors can find misstatements in financial reporting made by clients. However, the performance of the auditor's duties depends on his independence to report misstatements discovered during the examination. The results of hypothesis testing indicate that auditor independence does not affect fraud detection. These results indicate that the lower the level of auditor independence, the lower the auditor's ability to detect fraud. Auditors are influenced by pressure to defend their clients in terms of decision-making in the audit sector because of their sense of concern for clients. This concern arises from an auditor due to concerns about losing the company being audited. This concern is influenced by indicators related to the length of time an auditor has dealings with clients; These results indic ate that the longer an auditor is in contact with the client, the auditor will be emotionally bound to defend his client. The emotional relationship that exists between the auditor and the client due to the length of the relationship provides situational pressure that arises from within the auditor not to disappoint the client's wishes that have provided adequate audit fees, long contract duration, and the possibility of providing non-attestation services if this indicator is associated with weak indicators. A review of the fellow auditors, the auditors, are becoming less and less independent in the implementation of their work. The results showed that independence had a positive but insignificant effect on fraud detection with KAP samples in Makassar City. This study indicates that KAP in Makassar City is entirely independent in carrying out fraud detection. However, auditors still have to be aware of indicators that are likely to affect their independence.

It is consistent with the attribution theory, where auditor independence in fraud detection is related to external factors that affect the behavior of auditors. An auditor who has long performed an engagement with a client feels pressured to devote himself to that client as a form of remuneration because the client has awarded him an audit engagement contract. Pressure from clients can also be in the form of auditors' fear regarding the change of auditors by the client if the auditor does not provide the client's desired opinion. Furthermore, the amount of fees given by clients also affects the auditors' reaction so that it can reduce the level of independence of an auditor by overriding his independence. Weak peer review also affects auditor independence. A solid supervisory attribution theory will encourage auditors to be independent rather than sanctioned by the professional community. However, all of these indicators will not interfere with an auditor's independence if the internal factors that influence auditor behavior tend to be more substantial, such as the urge 
to apply professional ethics. This study is by research (Sulistyowati and Supriyati, 2016) which states that auditors are influenced by pressure to defend their clients in terms of decision making in the audit sector because of a sense of concern arising from an auditor with the possibility of losing the company being audited. Therefore, the auditor should not only be accessible in reality, but he should also avoid situations that make others doubt his freedom. Several things that can interfere with the independence of the auditor, such as the length of time for the audit between the client and the public accountant, audit fees, other services (other than audit services), and the profile of the Public Accounting Firm Research (Umar et al., 2019) found that the primary control that can eliminate the possibility of financial statement fraud is an independent audit where the independent auditor can provide a final evaluation to prevent the occurrence of such fraud. Auditors must maintain an attitude of independence and must be free from all interests that are inconsistent with integrity and objectivity in carrying out their audit duties in detecting fraud. Auditor independence is required to be free from the interests and pressures of any party. Therefore, the auditor can accurately detect whether there is fraud in the company being audited. Once fraud is detected, the auditor is not expected to be involved in securing the fraudulent practice.

The application of Ethics to fraud detection. This study indicates that the application of ethics has a positive and significant effect on fraud detection, and the third hypothesis (H3) is accepted. The working attitude of the auditors who consistently implement ethical standards will improve the performance of the auditors. This result is because auditors who implement ethical standards tend to carry out seriously the auditor's responsibility to detect fraudulent financial reports. The accuracy of the detection results of fraudulent financial statements will increase (Swastyami, 2016). According to applicable ethical standards, auditors who work in Makassar always review the audit evidence they obtain in carrying out their duties (Hajering et al., 2019). The results of this study imply that auditors are obliged to maintain their integrity by adhering to the code of ethics even though the compensation obtained from the audit activities is not by the auditors' expectations. This study also explains that the application of ethics in detecting fraud will maintain the objectivity and independence of auditors who prioritize public interests rather than personal interests. Auditors are also required to carry out audit ethics by understanding the scope and nature of the inspection work, namely by always carrying out examinations adhering to the established code of ethics and standards.

This study's findings are based on the theory of attribution, which explains how a person's behavior is influenced by a set of moral principles or values. Auditors tend to maintain ethical principles by consistently implementing a code of ethics by the Public Accountant Professional Standards. Auditors who behave ethically will have integrity and objectivity in carrying out their duties to detect fraudulent financial statements of their clients. The results of this study support research (Harahap and Putri, 2018; Idawati, 2020), which found that the application of a code of ethics affects the detection of fraud. The basic principles of professional ethics in the auditor's code of ethics will help the auditor detect fraud so that the auditor will be able to produce quality work according to the requirements of the public accounting professional standards.

Effect of workload on fraud detection. This study found that workload did not affect fraud detection, and the fourth hypothesis (H4) was rejected. The auditor's workload is related to 
the number of clients that must be handled by an auditor, while the auditor's time to carry out the audit process is limited (Yusrianti, 2015). Auditor workload is strongly influenced by the number of engagements, time of assignment, size of duties and responsibilities according to law, and limitations on the scope of audit duties and the company's economies of scale. The economy in Makassar City is not as big as the scale of companies in big cities such as DKI Jakarta or Surabaya City. These study results illustrate that the average KAP in Makassar City does not handle many companies and the size of the companies handled is also not as large as the cities of Jakarta and Surabaya. It, of course, affects the smaller number of engagements, shorter auditing time, not too large legal responsibilities, and less extensive limitations on the audit scope. These factors allow auditors to complete their work freely, ensuring that the workload does not interfere with the auditor's ability to detect fraud.

The results of this study support the attribution theory, which explains that auditors always consider the barriers that come from external sources in reacting to something. The workload of the auditor's ability will provide flexibility for auditors to detect fraud by carrying out their responsibilities without being overwhelmed by extensive audit objects. Large workloads also should not affect the ability of auditors to detect fraud because auditors are respondents who have the competence and technical skills to examine financial reports so that they are fully obliged to resolve any workload constraints that can affect their professional attitudes. The results of this study also support the results (Kamaliah and Safitri, 2017) and (Ranu and Merawati, 2017) found that workload does not affect the ability of auditors to detect fraud. The many tasks performed by the auditors make the audit feel overwhelmed and tired, but this is part of the auditor's determination and responsibility.

\section{CONCLUSION}

Based on the discussion and analysis conducted, the study's findings can be summarized as follows: experience and implementation ethic positively affect fraud detection. At the same time, fraud detection is unaffected by independence or workload. These findings suggest that Makassar City KAP auditors are becoming more independent in their task completion. This study recommends additional research to add and expand the area, sample size, and use of variables. This study's sample is still relatively small and limited to auditors who work at the Public Accounting Firm in Makassar. To gain a better understanding of how these factors affect fraud detection.

\section{REFERENCES}

Afiani, F. A., Latifah, N., dan Sukanto, E. (2019). Skeptisme Profesional, Pelatihan Audit Kecurangan, Pengalaman Audit dan Kemampuan Auditor dalam Mendeteksi kecurangan pada Inspektorat Kota dan Kabupaten di Jawa Tengah. Prosiding Mahasiswa Seminar Nasional Unimus. 2. Semarang: Universitas Muhammadiyah Semarang.

Amin, A. (2019). Praktek Akuntansi Dalam Bingkai Etika Siri'na Pacce : Persepsi Mahasiswa Akuntansi. ATESTASI Jurnal Ilmiah Akuntansi, 2 (1).

Anto, L., Mustafa, S., dan Florensia, A. (2020). Pengaruh Beban Kerja dan Pengalaman Auditor Terhadap Kemampuan Auditor Mendeteksi Kecurangan Pada Inspektorat 
Provinsi Sulawesi Tenggara. JUMBO : Jurnal Manajemen, Bisnis dan Organisasi, 4 (2), 01-13. http://ojs.uho.ac.id/index.php/JUMBO.

Dasila, R. A., dan Hajering, H. (2019). Pengaruh Pengalaman, Independensi dan Skeptisme Profesional Auditor Terhadap Pendetksian Fraud. Paradoks. Jurnal Ilmu Ekonomi, 2 (1).

Hajering, Su'un, M., and Muslim. (2019). Moderating Ethics Auditor Influence Of Competence, Accountability on Audit Quality. Jurnal Akuntansi, 23 (3).

Harahap, R. U., dan Putri, S. A. (2018). Pengaruh Penerapan Kode Etik dan Skeptisme Profesional Auditor Terhadap Pendeteksian Fraud Pada Kantor BPKP Perwakilan Provinsi Sumatera Utara. LIABILITIES. Jurnal Pendidikan Akuntansi, 1 (3) https://doi.org/10.30596/liabilities.v1i3.2554.

Hassan, R. (2019). Pengaruh Etika Profesi dan Independensi Auditor Terhadap Pendeteksian Fraud Dengan Profesionalisme Auditor Sebagai Variabel Moderasi. Jurnal Magister Akuntansi Trisakti, 6 (2).

Idawati, W. (2020). Analisis Pendeteksian Kecurangan Pada Laporan Keuangan. BAJ (Behavioral Accounting Journal), 3 (1).

Indrawati, L., Cahyono, D., dan Maharani, A. (2019). Pengaruh Skeptisisme Profesional, Independensi Auditor dan Pelatihan Audit Kecurangan Terhadap Kemampuan Mendeteksi Kecurangan. International Journal of Social Sciences \& Business., 3 (2). Kamaliah, V. D., dan Safitri, D. (2017). Pengaruh Beban Kerja, Pelatihan dan Tekanan Waktu Terhadap Kemampuan Auditor Mendeteksi Kecurangan. JOM Fekon Universitas Riau, 4 (1).

Karyono. (2013). Forensic Fraud. Yogyakarta: Andi.

Mokoagouw, M., Kalangi, L., dan Gerungai, N. (2018). Pengaruh Skeptisme Perofesional dan Pengalaman Auditor Terhadap Kemampuan Auditor Mendeteksi Kecurangan. (Survei Auditor BPK RI Perwakilan Sulawesi Utara). Going Concern : Jurnal Riset Akuntansi., 13 (2).

Molina, M., dan Wulandari, S. (2018). Pengaruh Pengalaman, Beban Kerja dan Tekanan Waktu Terhadap Kemampuan Auditor Mendeteksi Kecurangan. Jurnal Ilmu Akuntansi. Akunnas, 16 (2).

Mulyadi. (2016). Sistem Infromasi Akuntansi. Jakarta: Salemba Empat.

Muslim, Hamzah, A., Rahim, S., and Pelu, M. F. (2020). Client Pressures, Audit Tenure To Audit Quality : Moderation Of Auditor Independence. Journal of Auditing Finance and Forensic Accounting, 8 (2), 67-75.

Peuranda, J. H., Hasan, A., dan Silfi, A. (2019). Pengaruh Independensi, Kompetensi dan Skeptisme Profesional terhadap Kemampuan Auditor dalam Mendeteksi Kecurangan dengan Pelatihan Audit Kecurangan Sebagai Variabel Moderasi. Jurnal Ekonomi., 27 (1).

Prasetyo, S., Kamaliah, dan Hanif, R. A. (2015). Pengaruh Red Flags, Skeptisme Profesional Auditor, Kompetensi, Independensi dan Profesionalisme Terhadap Kemampuan Auditor Dalam Mendeteksi Kecurangan. JOM Fekon, 2(1).

Primasari, A., Mulyadi, J., dan Ahmar, N. (April 2019 p.). Pengaruh Independensi, Audit Tenure, Beban Kerja dan tekanan Waktu Terhadap Kemampuan Auditor dalam Mendeteksi Kecurangan Dengan Variabel Moderasi Pemahaman Kondisi Entitas dan Supervisi. JIMEA- Jurnal Inovasi Manajemen Ekonomi dan Akuntansi, 1(1). 
Rahim, S., Muslim, and Amin, A. (2019). Red Flag And Auditor Experience Toward Criminal Detection Trough Profesional Skepticism. Jurnal Akuntansi UNTAR, XXIII(1), 47-62.

Ranu, G. Y., dan Merawati, L. (Februari 2017). Kemampuan Mendeteksi Fraud Berdasarkan Skeptisme Profesional, Beban Kerja, Pengalaman Audit dan Tipe Kepribadian Auditor. JUARA : Jurnal Riset Akuntansi, 7(1).

Sania, A., Widaryanti, dan Sukanto, E. (2019). Skeptisme Profesional, Independensi, Tekanan Waktu, Pengalaman Audit dan Kemampuan Auditor dalam Mendeteksi Kecurangan. Prosiding Mahasiswa Seminar Nasional Unimus, 2. Semarang.

Sari Y.E, dan Helmayunita N. (2018). Pengaruh beban Kerja, Pengalaman dan Skeptisme Profesional Terhadap Kemampuan Auditor dalam Mendeteksi Kecurangan(Studi Empiris pada BPK RI Perwakilan Provinsi Sumatera Barat). Wahana Riset Akuntansi, $6(1)$.

Sari, K. A., Wirakusuma, M., dan Ratnadi, N. D. (2018). Pengaruh Skeptisme Profesional, Etika, Tipe Kepribadian, Kompensasi dan Pengalaman Pada Pendeteksian Kecurangan. E-Jurnal Ekonomi dan Bisnis Universitas Udayana, 7 (1).

Sekaran, U., dan Bougie, R. (2018). Research Methos For Business (Metodologi Penelitian untuk Bisnis). Jakarta: Salemba Empat.

Sugiyono. (2015). Metode Penelitian (Metode Kuantitatif, Kualitatif, R\&D). Bandung: Alfabeta.

Sulistiyanti, R. (2020). Pengaruh Independensi, Skeptisme Profesionalisme dan Audit Tenure Terhadap Kemampuan Aparat Pengawasan Internal Pemerintah Mendeteksi Kecurangan. BJRA : Bongaya Journal for Research in Accounting, 3 (2), 25-30.

Swastyami, A. P. (2016). Karaktersitik Auditor, Risiko Audit dan Tanggung Jawab Dalam Mendeteksi Kecurangan. Jurnal Akuntansi Bisnis, XV (29).

Ulfa, N. (2015). Pengaruh Pengalaman, Beban Kerja, dan Pelatihan Terhadap Skeptisme dan Kemampuan Auditor Mendeteksi Kecurangan. JOM Fekon, 2 (1), 2-11.

Yanti, R. T., dan Herlin. (2019). Analisis Pengalaman, Skeptisme Profesional Auditor Terhadap Kemampuan Mendeteksi Fraud. Jurnal Akuntansi Unihaz-JAZ, 2 (2).

Yulia, E., dan Nayang, H. (2018). Pengaruh Beban Kerja, Pengalaman dan Skeptisme Profesional Terhadap Kemampuan Auditor Dalam Mendeteksi Kecurangan (Studi Empiris Pada BPK RI Perwakilan Provinsi Sumatera Barat). Jurnal WRA., 6 (1), 1173-1192. 